\title{
ВИДЫ КОНТРОЛЯ УСПЕВАЕМОСТИ ОБУЧАЮЩИХСЯ В УСЛОВИЯХ ОНЛАЙН-ОБУЧЕНИЯ ИНОСТРАННОМУ ЯЗЫКУ В ВОЕННЫХ ВУЗАХ
}

\section{TYPES OF STUDENT PROGRESS CONTROL IN THE CONDITIONS OF ONLINE LEARNING FOREIGN LANGUAGE IN MILITARY UNIVERSITIES}

\section{Ostreiko}

Summary: The relevance of the work is confirmed by the search for new forms and methods of control by teachers of military universities in the framework of online education. The aim of the work is to create a list of types of control that are used by teachers of military universities in distance learning in a foreign language. The scientific novelty of the article is the material of the research «United States Armed Forces», which analyzes various types of control. A feature of the work is the use of the topic in foreign language classes in the context of distance learning. The author comes to the conclusion about a variety of types of control in the context of online learning and the possibility of conducting individual, group and frontal work with students of military academies.

Keywords: types of control of progress, students of military academies, military university, English, preliminary, current, thematic control.

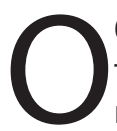
бразовательные системы стараются гибко адаптироваться к современным условиям. В «Национальной доктрине образования в Российской Федерации», одобренной Постановлением Правительства № 751, указано, что модели и формы онлайн-обучения входят в программу развития современного образования [3]. Кроме этого, преимуществом онлайн-обучения является возможность иметь круглосуточный доступ к информации, что так необходимо в процессе изучения иностранного языка с целью повторения и закрепления полученных знаний.

Актуальность работы обусловлена тем, что многие педагогические коллективы, в том числе и преподаватели военных вузов, находятся в постоянном поиске новых форм и методов контроля, подходящих системе дистанционного обучения. Исследователь И.В. Киян справедливо замечает, что от разнообразия форм контроля зависит реализация поставленных задач во время усвоения образовательной программы, специфика усвоения и проверка достижения необходимых образовательных результатов [2, с. 52]. Самым действенным видом контроля знаний в высшей школе исследователь считает выполнение курсовых и дипломных работ.
Острейко Лариса Владимировна

Дочент, Общевойсковая ордена Жукова Академия ВС РФ

larisa-vl@list.ru

Аннотация: Актуальность работы подтверждается поиском новых форм и методов контроля преподавателями военных вузов в рамках онлайн-обучения. Целью работы является создание списка видов контроля, применимых преподавателями военных вузов на дистанционных занятиях по иностранному языку. Научной новизной статьи является материал исследования «Вооруженные силы США», на котором проводится анализ различных видов контроля. Особенностью работы является применение темы на занятиях по иностранному языку в условиях дистанционного обучения. Автор приходит к выводу о разнообразии видов контроля в условиях онлайн-обучения и возможности проведения индивидуальной, групповой и фронтальной работы со слушателями военных академий.

Ключевые слова: виды контроля успеваемости, слушатели военных академий, военный вуз, английский язык, предварительный, текущий, тематический контроль.
Коллектив ученых «Военной академии связи» Е.А. Рябоконь, Л.А. Андреева и Е.Г. Копосова исследовали методику проведения и подготовки контрольных работ в военном вузе и пришли к выводу, что основным видом учебных занятий и элементом текущего контроля является выполнение контрольных и письменных работ [4, с. 120].

Как отмечает Е.В. Зимина, спецификой преподавания иностранного языка в военном вузе заключается в том, что слушателям военных академий необходимо изучить фонетические, лексические, морфологические и синтаксические нормы и овладеть понятиями будущей специальности через иностранный язык [1]. Профессионально ориентированное обучение иностранному языку в военном вузе должно быть направлено на оптимальное соотношение чтения, аудирования и говорения на разных этапах иноязычного образования. На каждом из этих этапов необходим контроль освоения темы, умения понимать, говорить и читать на иностранном языке.

Как отмечается в пособии В.А. Сластенина, выделяют четыре основных вида контроля: предварительный, текущий, тематический и итоговый [6, с. 231]. 
Предварительный контроль необходим для проверки уровня знаний слушателей военных академий, которые будут изучаться. Текущий контроль осуществляется в повседневной работе с целью проверки усвоения нового материала.

В онлайн-обучении текущий контроль может проходить в виде устного опроса слушателей военных академий на конференции Zoom или др. онлайн-платформы, проверки выполнения домашнего задания, контрольных работ, тестирования, выполнения самостоятельных работ, защита реферата, участие в семинаре, проч.

Тематический контроль в обучении иностранному языку проводится с целью закрепления новой темы. В военном вузе это могут быть разделы: «Вооруженные силы США», «Назначение и организация отдельных родов войск Вооруженных сил США» и др. Эти и др. разделы представлены в военно-теоретическом труде А.Н. Сидорина и др. исследователей[5, с. 542].
Итоговый контроль может проводиться в конце каждого семестра и представлять собой индивидуальную работу (курсовая работа, ВКР), групповую (проектная работа), фронтальный контроль (тестирование).

Необходимо отметить, что каждый обозначенный метод имеет свои достоинства, недостатки и область применения, поэтому их необходимо выполнять в комплексе, чтобы суметь оценить все аспекты образовательного процесса. Для этого сделаем тематический план изучаемых на иностранном языке тем исследования, представленный в табл. 1.

Таким образом, мы рассмотрели различные виды контроля успеваемости обучающихся военных вузов в условиях онлайн-обучения иностранному языку. Следует отметить, что основными видами предварительного контроля являются анкетирование, тестирование, беседы со слушателями военных академий, наблюдение за работой и лексиконом обучающихся.

Таблица 1.

Виды контроля, применимые на занятиях по иностранному языку в военном вузе

\begin{tabular}{|c|c|c|c|}
\hline \multirow{2}{*}{ Тема изучения } & \multicolumn{3}{|c|}{ Виды контроля } \\
\hline & Предварительный контроль & Текущий контроль & Тематический контроль \\
\hline United States Armed Forces & $\begin{array}{l}\text { Устный фронтальный опрос обуча- } \\
\text { ющихся на тему: «Структура войск } \\
\text { США» онлайн в Zoom-конференции }\end{array}$ & $\begin{array}{l}\text { Выполнение контрольных работ он- } \\
\text { лайн, лексических и грамматических } \\
\text { диктантов, составление диалогов. }\end{array}$ & $\begin{array}{l}\text { Лексический диктант: препо- } \\
\text { даватель называет род войск на } \\
\text { английском языке, а слушатели } \\
\text { военных академий создают текст } \\
\text { в Google форме и отправляют } \\
\text { сразу после диктанта. }\end{array}$ \\
\hline 1. United States Army & $\begin{array}{l}\text { Распределение названий войск по } \\
\text { родам на русском языке в виде та- } \\
\text { блицы в Google форме. Далее зна- } \\
\text { комство с английскими названиями. }\end{array}$ & $\begin{array}{l}\text { Диктант в картинках в формате он- } \\
\text { лайн на сопоставление различных } \\
\text { видов сухопутных войск. }\end{array}$ & $\begin{array}{l}\text { Выполнение тестовых заданий } \\
\text { на тему: «U.S. Armed Forces». }\end{array}$ \\
\hline $\begin{array}{l}\text { 2. Purpose, organization and } \\
\text { structure of the U.S. Coast Guard }\end{array}$ & $\begin{array}{l}\text { Знакомство с требованиями и усло- } \\
\text { виями изучения темы «United States } \\
\text { Armed Forces» в виде презентации. } \\
\text { Работа в группах в формате Zoom } \\
\text { конференции. }\end{array}$ & $\begin{array}{l}\text { Лексический диктант. Преподаватель } \\
\text { в формате онлайн-конференции по- } \\
\text { казывает схему сухопутных войск на } \\
\text { русском языке с пустыми клетками. } \\
\text { Обучающиеся вписывают недостаю- } \\
\text { щие рода войск. }\end{array}$ & $\begin{array}{l}\text { Онлайн-опрос: различение родов } \\
\text { войск, их назначения и структу- } \\
\text { ры на английском языке. }\end{array}$ \\
\hline $\begin{array}{l}\text { 3. Purpose, organization and } \\
\text { structure of the Air Force and } \\
\text { Air Force Reserve }\end{array}$ & $\begin{array}{l}\text { Беседа со слушателями военных } \\
\text { академий на тему различных родов } \\
\text { войск США на английском языке. }\end{array}$ & $\begin{array}{l}\text { Составление отдельных тематических } \\
\text { рассказов на темы: } \\
\text { 1. Air National Guard. } \\
\text { 2. Air Force. } \\
\text { 3. Air Force Reserve. }\end{array}$ & $\begin{array}{l}\text { Практическая работа в группах в } \\
\text { формате Zoom-конференции. }\end{array}$ \\
\hline $\begin{array}{l}\text { 4. Purpose, organization and } \\
\text { structure of the Navy and Navy } \\
\text { Reserve }\end{array}$ & $\begin{array}{l}\text { Анкетирование слушателей военных } \\
\text { академий в Google форме с целью } \\
\text { построения плана изучения темы на } \\
\text { английском языке. }\end{array}$ & $\begin{array}{l}\text { Составление и реализация диалогов } \\
\text { и полилогов на заранее составленные } \\
\text { темы на английском языке: } \\
\text { 1. History. } \\
\text { 2. Mobilization. } \\
\text { 3. Selected Reserve (SELRES). }\end{array}$ & $\begin{array}{l}\text { Устное представление различных } \\
\text { родов войск на английском языке } \\
\text { в формате Zoom-конференции. }\end{array}$ \\
\hline $\begin{array}{l}\text { 5. Purpose, organization and } \\
\text { structure of Marine Corps and } \\
\text { Marine Corps Reserve, Space } \\
\text { Force. }\end{array}$ & $\begin{array}{l}\text { Беседа со слушателями военных } \\
\text { академий на английском языке } 0 б \\
\text { известных им родах войск США. }\end{array}$ & $\begin{array}{l}\text { Составление устных рассказов по кар- } \\
\text { тинке, на которой изображен опреде- } \\
\text { ленный род войск в формате конфе- } \\
\text { ренции Zoom. }\end{array}$ & $\begin{array}{l}\text { Создание реферата на заданную } \\
\text { преподавателем тему. Защита } \\
\text { своей работы в формате Zoom- } \\
\text { конференции. }\end{array}$ \\
\hline
\end{tabular}


Видами текущего контроля в условиях онлайн обучения на иностранном языке могут быть: опросы, практические работы, тестирования, контрольные работы, лексические и грамматические диктанты, диалоги и полилоги между слушателями военных академий.

Тематический контроль представлен на материале изучения и закрепления темы «United States Armed Forces» и может быть представлен в виде практической работы, онлайн-опроса, тестовых заданий, а также лексического и грамматического диктанта по итогам изучения темы.

Кроме этого, в условиях изучения иностранного языка в формате дистанционного обучения также примени- мы различные формы работы. Индивидуальная работа допустима при выполнении тестовых работ, контрольных работ, анкетирования и др. в различных вариантах Google форм. При этом использование домашних работ и словарей не будет отражаться на выполнении итогового тестирования.

Групповая и фронтальная работа может использоваться в формате Zoom-конференций. Преподаватель может спрашивать как представителей группы, так и всех слушателей военных академий. Эта работа необходима для закрепления устной работы, работы в парах и группах при составлении диалогов и монологов на английском языке, а также проверки усвоения фонетических и грамматических правил английского языка.

\section{ЛИТЕРАТУРА}

1. Зимина Е.В. Особенности методики обучения иностранным языкам курсантов военного вуза в процессе непрерывного профессионального образования // Известия Российского государственного педагогического университета им. А.И. Герцена. - 2007. - № 2. - [Электронный ресурс]. - Режим доступа: https://cyberleninka.ru/article/n/osobennosti-metodiki-obucheniya-inostrannym-yazykam-kursantov-voennogo-vuza-v-protsesse-nepreryvnogoprofessionalnogo-obrazovaniya/viewer (дата обращения: 13.06.2021).

2. иян И.В. Варианты контроля знаний в системе дистанционного образования // Сибирский педагогический журнал. - 2018. - № 2. - С. 52-58.

3. Национальная доктрина образования в Российской Федерации [Электронный ресурс] - Режим доступа: http://dvgu.ru/umu/ZakRF/doktrinl.htm (дата обращения: 12.06.2021).

4. Рябоконь Е.А., Андреева Л.А., Копосова Е.Г. Методика подготовки и проведения контрольных работ по математике в военном вузе // Путь науки. 2016. - № 12 (34) - С. 120-123.

5. Сидорин А.Н., Акуленко В.П., Прищепов В.М. Вооруженные силы США в XXI веке. Военно-теоретический труд. - М.: Кучково поле, 2013. - 800 с.

6. Сластенин В.А. Педагогика: Учеб. пособие для студентов высш. пед. учеб. заведений / В.А. Сластенин, И.Ф. Исаев, Е.Н. Шиянов; Под ред. В.А. Сластенина. - M.: Academia, 2002. -566 c. 